\title{
Diallel Analysis of Diplodia Ear Rot Resistance in Maize
}

A. E. Dorrance, Department of Plant Pathology, Ohio State University, OARDC, Wooster 44691; and K. H. Hinkelmann, Department of Statistics, and H. L. Warren, Department of Plant Pathology, Physiology and Weed Science, Virginia Polytechnic Institute and State University, Blacksburg 24061-0331

\begin{abstract}
Dorrance, A. E., Hinkelmann, K. H., and Warren, H. L. 1998. Diallel analysis of Diplodia ear rot resistance in maize. Plant Dis. 82:699-703.

A diallel cross of seven inbreds and one synthetic line of maize were analyzed in 1994 and 1995 for their reaction to Diplodia ear rot. An additional inbred line was included in the 1995 analysis. Plants were inoculated by placing a pycnidiospore suspension $\left(5 \times 10^{3}\right.$ spores per $\left.\mathrm{ml}\right)$ of Stenocarpella maydis in the whorl at the V14 to V15 growth stage. Crosses were evaluated for disease incidence of Diplodia ear rot at harvest, and the percentage of plants with Diplodia ear rot in a plot was used for analysis. In both years, general combining ability (GCA) effects were significant. In 1995, specific combining ability effects were also significant. There were no reciprocal effects. There was no significant interaction between year and genotypes, indicating that crosses reacted the same in both years. Inbred lines B37, H111, B68, and MS had negative GCA effects that contributed toward resistance in both years. VA26, with intermediate resistance to Diplodia ear rot, contributed toward susceptibility. Only inbred lines with a high degree of resistance should be used as parents.
\end{abstract}

Additional keywords: breeding for resistance, corn, Zea mays

Diplodia ear rot, caused by the fungus Stenocarpella maydis (Berk.) Sutton (=Diplodia maydis (Berk.) Sacc.), is an important disease in many maize (Zea mays L.) growing regions of the world and was once the most important ear rot pathogen in the United States (15). Diplodia ear rot develops as a result of infection and subsequent inter- and intracellular colonization of the maize ear. S. maydis pycnidiospores germinate and colonize stalk, leaf, and shank tissues by directly penetrating epidermal cell walls and host cytoplasm through the formation of an appressorium and enzymatic degradation (1). Ears are usually colonized from the shank up into the ear, and losses are due to reduced seed weight and seed viability. Significant losses due to this disease have recently been reported from isolated locales within the United States (19; M. A. Hanson, 1992, VPI \& SU Department of Plant Pathology, Physiology and Weed Science, Plant Clinic Record 2102 and 2027; D. H. Scott, 1995, personal communication; P. C. Vincelli, 1993, 1994, personal communication).

Latterell and Rossi (17) suggested that increased incidence of Diplodia ear rot was related to changes in tillage practices. Flett

Corresponding author: A. E. Dorrance

E-mail: dorrance.1@osu.edu

Accepted for publication 12 February 1998.

Publication no. D-1998-0330-03R

(C) 1998 The American Phytopathological Society and Wehner (5) reported a higher incidence of Diplodia ear rot under conservation tillage systems. More pycnidia were produced and survived on maize stubble on the soil surface than on stubble buried in the soil (6). High disease incidences do not normally occur over wide areas but rather occur in isolated fields. A statewide average disease incidence of 1 to $2 \%$ has been recorded from field surveys throughout Indiana (23).

Diplodia ear rot is also an important ear rot from the perspective of mycotoxicosis. Diplodiosis is associated with the feeding of grain colonized by $S$. maydis to poultry, lambs, and ruminants in South Africa $(12,13,20)$.

Diplodia ear rot is best managed through the use of resistant hybrids (10). Previous reports concerning gene action for Diplofor Diplodia ear rot reaction dia ear rot resistance are conflicting. Koehler and Holbert (16) reported resistance to be dominant from studies of crosses between resistant and susceptible parents that were subjected to natural infection. Ullstrup (26) found that crosses with the most susceptible parent usually contributed susceptibility to the $F_{1}$ dependent on the year evaluated. In contrast, in crosses with resistant parents, the $F_{1} s$ were closer to the susceptible parent in one year and to the resistant parent in another year. Koehler (14) reported a significant correlation between the coverage of the ear by the husk and reduced ear rot development, and indicated that genes governing resistance may be additive. Wiser et al. (30) evaluated the percentage of cob infection in parents, $\mathrm{F}_{1} \mathrm{~s}$, and backcrosses, and reported that susceptibility was dominant. Crosses between two susceptible parents yielded progeny that were more susceptible than either parent. Additive effects were thought to be important for resistance to Diplodia ear rot in a study comparing two series of nine maize populations consisting of six generations: $\mathrm{P}_{1}, \mathrm{P}_{2}, \mathrm{~F}_{1}, \mathrm{~F}_{2}$, and backcrosses to both parents, $B_{1}$ and $B_{2}$ (27). Das et al. (2) reported that specific combining ability was more important than general combining ability when open pollinated maize varieties were mated in a diallel cross. Resistance to Diplodia ear rot is inherited independently from resistance to other ear rot pathogens (9) and to other diseases caused by $S$. maydis $(9,24)$.

Our research objective was to determine which inbreds conveyed resistance to Diplodia ear rot from a set of inbred lines and one synthetic that ranged in reaction from highly resistant to suscep-

Table 1. Pedigree and origin for lines used in the diallel cross to determine inheritance of resistance

\begin{tabular}{|c|c|c|c|c|c|}
\hline Inbred line & Reaction $^{x}$ & Pedigree $^{y}$ & Origin & Date released & Progeny tested \\
\hline H95 & $\mathrm{R}$ & OH43 $\times$ C.I.90A & Indiana & 1968 & 1995 \\
\hline B37 & $\mathrm{R}$ & Stiff Stalk Synthetic & Iowa & 1958 & $1994-95$ \\
\hline H111 & $\mathrm{R}$ & B $37 \times$ PI $209135^{z}$ & Indiana & 1982 & 1994-95 \\
\hline MS & MR & Mayorbela selections & Tropical & Not released & $1994-95$ \\
\hline B68 & I & $\begin{array}{l}\left(41.2504 \mathrm{~B} \times \mathrm{B} 14^{3}\right) \\
\text { selection }\end{array}$ & Iowa & 1968 & $1994-95$ \\
\hline Va26 & I & $\mathrm{OH} 43 \times \mathrm{K} 155$ & Virginia & 1967 & 1994-95 \\
\hline B73 & $\mathrm{S}$ & Stiff Stalk Synthetic & Iowa & 1972 & 1994-95 \\
\hline H99 & $\mathrm{S}$ & Illinois Synthetic $60 \mathrm{C}$ & Indiana & 1974 & 1994-95 \\
\hline MB271 & S & $\begin{array}{l}{[\mathrm{B} 73 \times(\mathrm{B} 73 \times \mathrm{MB} 118-2)]} \\
\mathrm{S}_{2} \mathrm{BX}^{1}\end{array}$ & Tropical & Not released & $1994-95$ \\
\hline
\end{tabular}

\footnotetext{
${ }^{\mathrm{x}}$ Ratings for Diplodia ear rot: $\mathrm{R}=$ resistant, $\mathrm{MR}=$ moderately resistant, $\mathrm{I}=$ intermediate, and $\mathrm{S}=$ susceptible (H. L. Warren, unpublished data).

y References: Henderson (8) and Warren (28).

${ }^{\mathrm{z}}$ PI 209135 is a synthetic of tropical origin referred to as Mayorbela (28).
} 
tible by means of a diallel analysis. Several of these inbred lines were used in the development of modern maize inbreds.

\section{MATERIALS AND METHODS}

Parents (Table 1) were selected based on screening for disease reaction in the field (H. L. Warren, unpublished data). Seven inbred lines and one synthetic (Table 1) were crossed in all possible combinations in Virginia during the 1992 and 1993 growing seasons; an additional parent was included in 1994. Reaction to Diplodia ear rot was evaluated at the Kentland Agricultural Research Farm of Virginia Polytechnic Institute and State University, Blacksburg, on a Purdy silt loam soil with a 0 to $2 \%$ slope. The genotypes were planted in a randomized complete block with singlerow plots and four replications in 1994, and two-row plots with three replications in 1995. Seeds were planted by hand in 1994 and with a two-row plot planter (Almaco Corp., Johnson City, IA) in 1995. Rows were $3.3 \mathrm{~m}$ long with $0.75-\mathrm{m}$ spacing. Plots were separated by $1.52-\mathrm{m}$-wide alleys. Lime was applied at the rate of $4,480 \mathrm{~kg} / \mathrm{ha}$ in April 1994. Fertilizer was disk-incorporated at the rate of $168 \mathrm{~kg} \mathrm{~N}$, $45 \mathrm{~kg} \mathrm{P}$, and $67 \mathrm{~kg} \mathrm{~K}$ per ha prior to planting. Preplant herbicides applied included atrazine (1.7 kg a.i./ha) and simazine (1.1 $\mathrm{kg}$ a.i./ha). Postemergent herbicide treatments included bentazone (1.12 kg a.i./ha; BASF AG, Research Triangle Park, NC) and dicamba (0.14 kg a.i./ha; Sandoz Agro, Inc., DesPlaines, IL) and crop oil concentrate $(1.0 \% \mathrm{vol} / \mathrm{vol})$. In 1995 , only bentazone (1.12 kg a.i./ha) was applied as a postemergent herbicide. Nicosulfuron $(0.02$ kg a.i./ha; DuPont Agricultural Products, Wilmington, DE) was used to spot treat some grasses. Tefluthrin insecticide (18.3 $\mathrm{kg}$ a.i./ha; Zeneca Ag Products, Wilmington, DE) was applied in the furrow at planting. In 1994, the plots were irrigated with $2.5 \mathrm{~cm}$ of water on 22 and 23 June and 7 July to assure plant survival during prolonged drought periods.

Inoculum was produced in the following manner: maize kernels were placed in glass petri dishes and autoclaved for $1 \mathrm{~h}$ on 2 consecutive days. Fifteen autoclaved kernels were then placed on acidified potato dextrose agar (APDA, pH 5.5). Plates were seeded with pycnidiospores of an isolate of $S$. maydis from a diseased ear originating from the Kentland Agricultural Research Farm. Isolates were obtained from the same diseased ear in each year of the study. $S$. maydis was grown at room temperature or in an incubator at 25 to $27^{\circ} \mathrm{C}$ under $24-\mathrm{h}$ light (24-W cool white; General Electric, Cleveland, $\mathrm{OH}$ ). After 3 weeks, colonized kernels were placed in a flask with distilled water and shaken for 10 to $20 \mathrm{~min}$ to release the pycnidiospores, which were then filtered through four layers of cheesecloth. Pycnidiospores were counted using a hemacytometer and diluted to a final concentration of $5 \times 10^{3}$ spores per $\mathrm{ml}$ in the field prior to inoculations. Inoculation of germ plasm was conducted as described by Warren and Onken (29), where approximately $5 \mathrm{ml}$ of the spore suspension was placed in the whorl of the maize plants with a pressurized sprayer approximately 2 weeks prior to flowering at the V14 to V15 growth stage (21).

All plants in each row were rated for Diplodia ear rot incidence at harvest in 1994 and 1995. The ear of each plant was husked and examined for the presence of $S$. maydis mycelium. The ears were broken and examined for the presence of pycnidia at the base of the kernels when there was minimal mycelium present or multiple ear rot pathogens. Both disease severity and percent ear colonized were noted, but only percent incidence of Diplodia ear rot in each plot was used in the analysis. Disease severity was not analyzed because, following initial infection, colonization of maize ears by $S$. maydis is thought to be limited more by the moisture content of the grain rather than by host resistance. In 1994, the full diallel was first analyzed with a nonorthogonal analysis of variance (11) due to the low stand count (10 to 15 plants per plot) and missing crosses caused by poor growing conditions. Reciprocal crosses were combined, and the subsequent data set was then analyzed using a software program from S. B. Linda (IFAS, Department of Statistics, University of Florida) for Model 1, Method 4 of Griffing (7). Because of a large error term, the possibility of a cross by replicate interaction was also investigated using Tukey's test for non-additivity (25) with the following model:

$$
y_{i j k}=\mu+g_{i}+g_{j}+s_{i j}+r_{k}+a c_{i j} r_{k}+e_{i j k}
$$

where the $g_{i}, g_{j}$, and $s_{i j}$ represent the general combining abilities (GCA) of genotypes $i$ and $j$ and specific combining ability (SCA) of the cross between genotypes $i$ and $j$, respectively, $r_{k}$ represents the replication effect, and $a c_{i j} r_{k}$ represents a particular form of cross by replicate interaction with $a$ as a constant, $c_{i j}$ being the effect of the cross $i \times j$. In 1995, the full diallel was analyzed again, reciprocal crosses were combined, and the same analysis was conducted but without cross by replicate interaction. The genotypes that were common to both the 1994 and 1995 experiments were analyzed for GCA, SCA, year effects, and cross by year interactions with the general least squares analysis of diallel experiment program (22). Differences in GCA values for the parents were compared as described by Griffing (7). The percent means for each genotype were not normally distributed as determined by Proc Univariate procedure (SAS Institute, Cary, NC). Diplodia ear rot incidence was arcsine transformed and ranked according to the Proc Rank procedure of SAS. The

Table 2. Analysis of variance of Diplodia ear rot ratings for a half diallel cross involving eight parents in 1994, nine parents in 1995, and crosses common in both years combined

\begin{tabular}{|c|c|c|c|c|c|c|c|c|c|}
\hline \multirow[b]{2}{*}{ Source } & \multicolumn{3}{|c|}{1994} & \multicolumn{3}{|c|}{1995} & \multicolumn{3}{|c|}{ Combined $^{\mathbf{u}}$} \\
\hline & df & $\mathbf{M S}^{\mathbf{v}}$ & $F$ value $^{w}$ & df & MS & $F$ value & df & MS & $F$ value \\
\hline Year & $\ldots$ & $\cdots$ & $\ldots$ & $\ldots$ & $\ldots$ & $\ldots$ & 1 & 239.6 & \\
\hline Crosses & 27 & 107.7 & $2.58 * *$ & 35 & 241.4 & $8.83 * *$ & $\ldots$ & $\ldots$ & $\ldots$ \\
\hline $\mathrm{GCA}^{\mathrm{x}}$ & 7 & 277.8 & $6.65^{* *}$ & 8 & 103.3 & $11.34 * *$ & 7 & 505.3 & $12.1 * *$ \\
\hline $\mathrm{SCA}^{\mathrm{y}}$ & 20 & 48.2 & 1.15 & 27 & 73.67 & $8.08 * *$ & 20 & 298.9 & $7.14 * *$ \\
\hline Replicate & 3 & 31.3 & & 2 & 28.01 & & $\ldots$ & $\ldots$ & \\
\hline Replicate/year & $\ldots$ & $\ldots$ & $\ldots$ & $\ldots$ & $\ldots$ & $\ldots$ & 5 & 17.4 & \\
\hline Cross $\times$ year & $\ldots$ & $\ldots$ & $\ldots$ & $\ldots$ & $\ldots$ & $\ldots$ & 7 & 42.3 & 1.01 \\
\hline Cross $\times$ replicate & $1^{\mathrm{z}}$ & 870.4 & $20.8 * *$ & $\ldots$ & $\ldots$ & $\ldots$ & $\ldots$ & $\ldots$ & $\ldots$ \\
\hline Error & 80 & 41.8 & & 70 & 9.11 & & 154 & 41.9 & \\
\hline Total & 111 & & & 107 & & & 194 & & \\
\hline
\end{tabular}

u Comparison of $F_{1}$ s common to both 1994 and 1995.

${ }^{\mathrm{v}}$ Mean squares.

${ }^{\text {w }}$ Asterisks indicate that the effect is significant at $P \leq 0.01$.

${ }^{\mathrm{x}}$ General combining ability.

${ }^{y}$ Specific combining ability.

${ }^{\mathrm{z}}$ One degree of freedom test for non-additivity (25). 
rankings of the $\mathrm{F}_{1} \mathrm{~s}$ were compared using the Waller Duncan $k$-ratio test.

\section{RESULTS AND DISCUSSION}

Both growing seasons were marked by periods of drought that occurred at different times. By harvest, 1,994 plants were available for study in 1994. The final number of plants in 1995 was 3,942 because of more favorable growing conditions and the use of two-row plots. In both years, the ANOVA on whole plot data showed no reciprocal differences among the crosses. This indicated that maternal effects were not important, and breeders may use either line as the ear parent when breeding for resistance. However, in seed production areas where Diplodia ear rot is a problem, using the resistant parent as the ear parent will reduce the possibility of losses due to low seed viability as a result of Diplodia ear rot infection.

The GCA effects were significant for the $F_{1} s$ in 1994 and 1995 (Table 2). The SCA effects were not significant in 1994 but were significant in 1995. There was a highly significant cross by replicate interaction in 1994, which indicated that genotypes did not act the same in each replicate. The environmental conditions were quite challenging in 1994. Early drought conditions resulted in uneven stand counts, which may have influenced the disease incidence ratings as a result of variable numbers of plants of specific genotypes among the blocks. Uneven distribution of water from irrigation may also provide an explanation for the genotype by replication interaction in crosses. In 1995, the crosses were highly significant with a small error term, so the cross by replicate interaction was not tested. In a combined ANOVA for the crosses tested in both years (Table 2), the effect of the cross by year interaction was not significant. This indicated that the majority of the genotypes reacted similarly to inoculation both years, although there was a higher disease incidence in 1995 than in 1994. This may have been due to the combination of drought during anthesis followed by a rainy period prior to and during ear rot evaluations in 1995, conditions reported to favor Diplodia ear rot development (17). Matzinger et al. (18) reported considerable variance of specific combining ability over environments for yield of maize in a diallel analysis consisting of unselected parents. Our parents were fixed; however, the different environments between 1994 and 1995 may account for the change in the significance of the SCA effects.

The cross MB271 $\times$ B73 had very high levels of Diplodia ear rot both years (Tables 3 and 4). SCA effects indicate which combinations were better or worse compared with the group as a whole, and these effects are indicative of dominant gene action or epistasis. The magnitude of SCA effects in 1995 indicate that susceptibility may be dominant over resistance. For example, the SCA effect for the genotype MB271 $\times$ B73 was 33.6 , which was much higher and greater in magnitude than any of the other genotypes. These results agree with Wiser et al. (30), who reported that susceptibility may be dominant. Villena (27) also reported SCA effects were significant in one maize population.

Negative values for general combining abilities indicate a contribution toward resistance to Diplodia ear rot (Table 5). In both years, B37, H111, B68, and MS (Madison Synthetic) had negative GCA values for resistance. In 1995, the only year it was tested, H95 also had negative GCA values for resistance. Combinations with these parents should increase resistance to Diplodia ear rot even in years when the environment is highly favorable for disease development. Inbred H99 contributed toward resistance in 1994 but contributed toward susceptibility in 1995 . H99 is susceptible to Diplodia ear rot, and the low levels of Diplodia ear rot in 1994 may have given a false reading for this genotype. Parents B73, MB271, and VA26 contributed toward susceptibility in both years. MB271 is derived from a cross be-

Table 5. Comparison of general combining abilities (GCA) of maize parents tested in 1994 and 1995

\begin{tabular}{lllll}
\hline & 1994 & & & 1995 \\
\cline { 5 - 5 } \cline { 5 - 5 } Parent & GCA $^{\mathbf{z}}$ & & Parent & GCA \\
\hline B68 & $-4.27 \mathrm{a}$ & & B68 & $-5.48 \mathrm{a}$ \\
H111 & $-3.20 \mathrm{a}$ & & B37 & $-3.82 \mathrm{ab}$ \\
H99 & $-2.04 \mathrm{ab}$ & & MS & $-3.52 \mathrm{ab}$ \\
B37 & $-1.51 \mathrm{ab}$ & & H111 & $-2.03 \mathrm{ab}$ \\
MS & $-0.68 \mathrm{ab}$ & & VA26 & $0.44 \mathrm{bc}$ \\
MB271 & $3.62 \mathrm{~b}$ & & H99 & $1.29 \mathrm{bc}$ \\
VA26 & $3.98 \mathrm{~b}$ & & B73 & $5.42 \mathrm{c}$ \\
B73 & $4.09 \mathrm{~b}$ & MB271 & $7.69 \mathrm{c}$ \\
\hline
\end{tabular}

${ }^{\mathrm{z}}$ Numbers followed by the same letter do not differ significantly at $P=0.01$.

Table 3. $F_{1}$ cross means of percent incidence of Diplodia ear rot in harvested ears (above the diagonal) and specific combining ability effects (below the diagonal) for a set of diallel crosses among maize inbred lines evaluated in 1994, Kentland Agricultural Research Farm, Blacksburg, VA

\begin{tabular}{lrrrrrrrr}
\hline Parents & B37 & H111 & B68 & VA26 & MS & B73 & H99 & MB271 \\
\hline B37 & & 2.93 & 0.00 & 6.43 & 3.00 & 7.43 & 3.78 & 3.23 \\
H111 & 2.51 & & 0.00 & 2.00 & 2.08 & 3.85 & 2.38 \\
B68 & 0.66 & 2.35 & & 3.32 & 3.50 & 1.40 & 0.00 \\
VA26 & -1.16 & -3.90 & -1.50 & & 9.25 & 16.13 & 5.20 \\
MS & 0.06 & 0.83 & 3.32 & 0.82 & & 7.00 \\
B73 & -0.27 & -2.16 & -3.54 & 2.94 & -1.24 & & 2.78 & 3.38 \\
H99 & 2.21 & 2.50 & 1.19 & -1.85 & 0.38 & -4.13 & & 3.04 \\
MB271 & -4.00 & -2.11 & -2.47 & 4.65 & -4.19 & 8.40 & -0.29 \\
\hline
\end{tabular}

Table 4. $F_{1}$ cross means of the percent incidence of Diplodia ear rot in harvested ears (above the diagonal) and specific combining ability effects (below the diagonal) for a set of diallel crosses among maize inbred lines evaluated in 1995, Kentland Agricultural Research Farm, Blacksburg, VA

\begin{tabular}{lrrrrrrrrr}
\hline Parents & B37 & H111 & B68 & VA26 & MS & B73 & H99 & MB271 & H95 \\
\hline B37 & & 3.30 & 1.40 & 1.31 & 0.00 & 0.53 & 16.90 & 4.61 & 1.61 \\
H111 & 0.12 & & 3.77 & 7.81 & 2.19 & 4.51 & 12.44 & 4.77 & 14.64 \\
B68 & 2.42 & 1.41 & & 2.66 & 4.76 & 1.39 & 1.39 & 2.71 \\
VA26 & -2.22 & 0.88 & -0.06 & & 10.98 & 10.01 & 5.61 & 15.24 & 2.29 \\
MS & 0.04 & -1.15 & 5.61 & 7.28 & & 4.16 & 0.74 & 6.96 & 1.11 \\
B73 & -7.47 & -6.89 & -5.81 & -1.75 & -4.02 & & 10.86 & 52.07 & 3.71 \\
H99 & 12.28 & 4.41 & -2.44 & -2.78 & -4.08 & -2.01 & & 10.77 \\
MB271 & -5.57 & -8.81 & -6.67 & 1.31 & -3.40 & 33.66 & -4.28 & \\
H95 & 0.40 & 10.04 & 5.53 & -2.67 & -0.27 & -5.72 & -1.09 & -6.23 & 5.39 \\
\hline
\end{tabular}


tween a selection from Mayorbela and B73. Its susceptibility to Diplodia ear rot may have derived from B73. In previous tests, inbred VA26 had intermediate resistance to Diplodia ear rot (3; H. L. Warren, unpublished data). These results indicate that only those inbreds with high levels of resistance should be used to transfer resistance to breeding lines.

Mean disease incidence for the entire 1995. The mean incidence of Diplodia ear rot per plot ranged from 0.0 to $21.3 \%$ in 1994 and 0.0 to $52.1 \%$ in 1995 . Many of the genotypes had higher levels of disease incidence in 1995 than in 1994 (Table 6). Nine of the genotypes had greater than $10 \%$ incidence of Diplodia ear rot compared with only three genotypes in 1994. Genotypes with H99 combinations had higher disease incidence in 1995 than in 1994.

Resistant maize hybrids may have limited value in disease management when inoculum is abundant and weather is favorable for infection (4). There are few reports experiment was $5.1 \%$ in 1994 and $6.8 \%$ in on the environmental effects that influence Diplodia ear rot infection and colonization in maize. With the increased incidence of this maize pathogen, research in the area of environmental influence on Diplodia ear rot resistance would be useful. Maize hybrids with higher levels of resistance than currently available are needed to withstand about by changing agricultural practices. We have examined high inoculum levels and their effect on resistant lines (3), but tial are areas where more research is needed. Information on inoculum levels would provide growers with a better indication of when to employ cultural techniques, such as deep plowing of corn refuse, to reduce inoculum potential.

Parents used in the diallel cross were selected because of their known reaction to S. maydis. In addition, it was important to use parents in this study where the pedigrees were known. Public and private institutions may now examine their pedigrees for those lines that contain the parents that high levels of disease pressure brought quantifying inoculum and inoculum poten-

impart resistance or susceptibility to Diplodia ear rot. For example, one inbred line, B73 or its derivatives, which is highly susceptible to Diplodia ear rot, was utilized extensively in the development of modern inbreds for female parents in U.S. maize seed production.

From this study of a diallel analysis of resistance to Diplodia ear rot in maize, we found that reciprocal effects do not play a role in resistance to this disease, and GCA effects were predominant both years. Inbred lines B37, H111, B68, H95, and Madison Synthetic are good sources of resistance. In addition, breeding efforts should focus on parents with high levels of Diplodia ear rot resistance.

\section{ACKNOWLEDGMENTS}

We thank John Wooge, Claude Kenley, Stanley Long, Lloyd Flinchum, Alice Way, Scott Hagood, and John Eberwine for technical assistance and the VPI \& SU Whitethorne Research Farm Crew for assistance with irrigation. We also thank Modan Das and Erik Stromberg for numerous discussions and Michele Marini for help with the statistical analysis. This work was funded in part by Pioneer Hibred International. Approved by Virginia Polytechnic Institute and State University Experiment Station.

Table 6. Ranks of arcsine transformed percentages of Diplodia ear rot caused by Stenocarpella maydis from a maize diallel cross in 1994 and 1995, Kentland Agricultural Research Farm, Blacksburg, VA

\begin{tabular}{|c|c|c|c|c|c|}
\hline \multirow[b]{2}{*}{ Cross } & \multicolumn{2}{|c|}{1994} & \multirow[b]{2}{*}{ Cross } & \multicolumn{2}{|c|}{1995} \\
\hline & Mean ${ }^{y}$ & $\operatorname{Rank}^{\mathrm{z}}$ & & Mean & Rank \\
\hline B73 × VA26 & 16.1 & $\mathrm{a}$ & $\mathrm{B} 73 \times \mathrm{MB} 271$ & 52.1 & $\mathrm{a}$ \\
\hline $\mathrm{B} 73 \times \mathrm{MB} 271$ & 21.3 & $\mathrm{ab}$ & $\mathrm{B} 37 \times \mathrm{H} 99$ & 16.9 & $a b$ \\
\hline VA26 $\times$ MB271 & 17.4 & $\mathrm{ab}$ & VA $26 \times$ MB2 271 & 15.2 & $\mathrm{abc}$ \\
\hline $\mathrm{B} 73 \times \mathrm{B} 37$ & 7.4 & $\mathrm{abc}$ & $\mathrm{H} 111 \times \mathrm{H} 99$ & 12.4 & abcd \\
\hline $\mathrm{MS} \times \mathrm{B} 73$ & 7.3 & $a b c$ & H99 × MB271 & 10.8 & abcd \\
\hline H99 × MB271 & 6.4 & $a b c$ & VA26 $\times$ MS & 11.0 & abcde \\
\hline B37 × VA26 & 6.4 & $a b c$ & $\mathrm{H} 111 \times \mathrm{VA} 26$ & 7.8 & abcdef \\
\hline VA26 × H99 & 5.2 & $a b c$ & B73 × H99 & 10.9 & abcdef \\
\hline $\mathrm{H} 111 \times \mathrm{MB} 271$ & 3.4 & $a b c$ & H111 × H95 & 14.6 & abcdef \\
\hline $\mathrm{B} 68 \times \mathrm{MS}$ & 3.5 & $a b c$ & $\mathrm{~B} 73 \times \mathrm{VA} 26$ & 10.0 & abcdefg \\
\hline $\mathrm{MS} \times \mathrm{MB} 271$ & 3.9 & $a b c$ & $\mathrm{~B} 68 \times \mathrm{H} 95$ & 5.9 & abcdefgh \\
\hline $\mathrm{H} 111 \times \mathrm{B} 73$ & 3.8 & $\mathrm{abc}$ & $\mathrm{MS} \times \mathrm{MB} 271$ & 7.0 & abcdefghi \\
\hline $\mathrm{B} 37 \times \mathrm{H} 99$ & 3.8 & $a b c$ & $\mathrm{MB} 271 \times \mathrm{H} 95$ & 5.4 & abcdefghi \\
\hline $\mathrm{B} 68 \times \mathrm{VA} 26$ & 3.3 & $\mathrm{abc}$ & VA26 $\times$ H99 & 5.6 & bcdefghij \\
\hline B $73 \times$ H99 & 3.0 & $\mathrm{abc}$ & $\mathrm{H} 111 \times \mathrm{B} 73$ & 4.5 & bcdefghijk \\
\hline $\mathrm{B} 37 \times \mathrm{MB}$ & 3.2 & $\mathrm{abc}$ & $\mathrm{H} 111 \times \mathrm{MB} 271$ & 4.8 & bcdefghijk \\
\hline B $37 \times \mathrm{H} 111$ & 2.9 & $\mathrm{abc}$ & $\mathrm{H} 99 \times \mathrm{H} 95$ & 5.0 & bcdefghijk \\
\hline VA $26 \times \mathrm{MS}$ & 9.2 & $\mathrm{bc}$ & $\mathrm{B} 37 \times \mathrm{MB} 271$ & 4.6 & bcdefghijk \\
\hline $\mathrm{B} 37 \times \mathrm{MS}$ & 3.0 & $\mathrm{bc}$ & $\mathrm{MS} \times \mathrm{B} 73$ & 4.2 & cdefghijk \\
\hline $\mathrm{MS} \times \mathrm{H} 99$ & 2.8 & $\mathrm{bc}$ & B $37 \times \mathrm{H} 111$ & 3.3 & cdefghijk \\
\hline $\mathrm{H} 111 \times \mathrm{VA} 26$ & 2.0 & $\mathrm{bc}$ & $\mathrm{B} 73 \times \mathrm{H} 95$ & 3.7 & cdefghijk \\
\hline $\mathrm{H} 111 \times \mathrm{H} 99$ & 2.4 & $\mathrm{bc}$ & $\mathrm{B} 68 \times \mathrm{MB} 271$ & 2.7 & defghijk \\
\hline $\mathrm{H} 111 \times \mathrm{MS}$ & 2.1 & $\mathrm{bc}$ & $\mathrm{B} 68 \times \mathrm{VA} 26$ & 2.7 & efghijk \\
\hline $\mathrm{B} 68 \times \mathrm{MB} 271$ & 2.0 & bc & $\mathrm{B} 68 \times \mathrm{MS}$ & 4.8 & efghijk \\
\hline $\mathrm{B} 68 \times \mathrm{B} 73$ & 1.4 & bc & $\mathrm{H} 111 \times \mathrm{B} 68$ & 3.8 & efghijk \\
\hline $\mathrm{B} 37 \times \mathrm{B} 68$ & 0.0 & $\mathrm{c}$ & VA26 $\times$ H95 & 2.3 & efghijk \\
\hline B $68 \times$ H99 & 0.0 & $\mathrm{c}$ & $\mathrm{H} 111 \times \mathrm{MS}$ & 2.2 & fghijk \\
\hline $\mathrm{H} 111 \times \mathrm{B} 68$ & 0.0 & $\mathrm{c}$ & $\mathrm{B} 37 \times \mathrm{H} 95$ & 1.6 & ghijk \\
\hline & & & $\mathrm{B} 37 \times \mathrm{B} 68$ & 1.4 & hijk \\
\hline & & & $\mathrm{B} 68 \times \mathrm{B} 73$ & 1.4 & hijk \\
\hline & & & B68 × H99 & 1.4 & hijk \\
\hline & & & $\mathrm{B} 37 \times \mathrm{VA} 26$ & 1.3 & hijk \\
\hline & & & $\mathrm{H} 95 \times \mathrm{MS}$ & 1.1 & hijk \\
\hline & & & $\mathrm{MS} \times \mathrm{H} 99$ & 0.7 & ijk \\
\hline & & & $\mathrm{B} 73 \times \mathrm{B} 37$ & 0.5 & $\mathrm{jk}$ \\
\hline & & & $\mathrm{B} 37 \times \mathrm{MS}$ & 0.0 & $\mathrm{k}$ \\
\hline
\end{tabular}

\footnotetext{
${ }^{y}$ Mean percentage of the maize plants with Diplodia ear rot in a plot.

${ }^{\mathrm{z}}$ Ranks determined according to the Proc Rank procedure in SAS (SAS Institute, Cary, NC). Means followed by letters in common within years do not differ significantly according to ANOVA of
} ranked arcsine transformed percentages and Waller-Duncan $k$-ratio test $(P<0.05)$.

\section{LITERATURE CITED}

1. Bensch, M. J., and Van Staden, J. 1992. Ultrastructural histopathology of infection and colonization of maize by Stenocarpella maydis (=Diplodia maydis). J. Phytopathol. 136:312-318.

2. Das, S. N., Chattopadhyay, S. B., and Basak, S. L. 1984. Inheritance of resistance to diplodia ear rot of maize. Sabrao J. 16:149-152.

3. Dorrance, A. E. 1995. Diallel analysis of Diplodia ear rot resistance in maize and an assessment of the genetic variability of Stenocarpella maydis through isozyme analysis. Ph.D. diss. Virginia Polytechnic Institute and State University, Blacksburg.

4. Flett, B. C., and McLaren, N. W. 1994. Optimum disease potential for evaluating resistance to Stenocarpella maydis ear rot in corn hybrids. Plant Dis. 78:587-589.

5. Flett, B. C., and Wehner, F. C. 1991. Incidence of Stenocarpella and Fusarium cob rots in monoculture maize under different tillage systems. J. Phytopathol. 133:327-333.

6. Flett, B. C., Wehner, F. C., and Smith, M. F. 1992. Relationship between maize stubble placement in soil and survival of Stenocarpella maydis (Diplodia maydis). J. Phytopathol. 134:33-38.

7. Griffing, B. 1956. Concept of general and specific combining ability in relation to diallel crossing systems. Aust. J. Biol. Sci. 9:463493.

8. Henderson, C. B. 1980. Maize Research and Breeders Manual No. IX. Illinois Foundation

9. Hooker, A. L. 1956. Association of resistance to several seedling, root, stalk, and ear diseases in corn. Phytopathology 46:379-384.

10. Hooker, A. L., and White, D. G. 1976. Prevalence of corn stalk rot fungi in Illinois. Plant Dis. Rep. 60:1032-1034.

11. Huber, D. A., White, T. L., Littel, R. C., and Hodge, G. R. 1992. Ordinary least squares estimation of general and specific combining abilities from half-diallel mating designs. Silvae Genet. 41:263-273.

12. Kellerman, T. S., Prozesky, L., Anitra Schultz, R., Rabie, C. J., Van Ark, H., Maartens, B. P., and Lubben, A. 1991. Perinatal mortality in Seeds, Inc., Champaign, IL. 
lambs of ewes exposed to cultures of Diplodia maydis (=Stenocarpella maydis) during gestation. Onderstepoort J. Vet. Res. 58:297-308.

13. Kellerman, T. S., Rabie, C. J., VanDerWesthuizen, G. C. A., Kriek, N. P. J., and Prozesky, L. 1985. Induction of diplodiosis, a neuromycotoxicosis in domestic ruminants with cultures of indigenous and exotic isolates of Diplodia maydis. Onderstepoort J. Vet. Res. 52:35-42.

14. Koehler, B. 1953. Ratings of some yellow corn inbreds for ear rot resistance. Plant Dis. Rep. 37:440-444.

15. Koehler, B. 1959. Corn ear rots in Illinois. Il. Agric. Exp. Stn. Bull. 639.

16. Koehler, B., and Holbert, J. R. 1930. Corn Diseases in Illinois, Their Extent, Nature, and Control. Ill. Agric. Exp. Stn. Bull. 354.

17. Latterell, F. M., and Rossi, A. E. 1983. Stenocarpella macrospora (=Diplodia macrospora) and $S$. maydis (=D. maydis) compared as pathogens of corn. Plant Dis. 67:725-729.
18. Matzinger, D. F., Sprague, G. F., and Cockerham, C. C. 1959. Diallel crosses of maize in experiments repeated over locations and years. Agron. J. 51:346-350.

19. Munkvold, G. P., and Yang, X. B. 1995. Crop damage and epidemics associated with 1993 floods in Iowa. Plant Dis. 79:95-101.

20. Rabie, C. J., DuPreez, J. J., and Hayes, J. P. 1987. Toxicity of Diplodia maydis to broilers, ducklings and laying chicken hens. Poultry Sci. 66:1123-1128.

21. Ritchie, S. W., and Hanway, J. J. 1992. How a corn plant develops. Iowa Coop. Ext. Ser. Spec. Rep. No. 48, Ames, IA

22. Schaffer, H. E., and Usanis, R. A. 1995. General least squares analysis of diallel experiment program. North Carolina State University Department of Genetics, Raleigh, NC.

23. Scott, D. H., Grogan, J., Gann, R., Everson, R. J., and Binkerd, K. 1992. Summary of 1989, 1990, and 1991 pre-harvest corn ear rot/mycotoxin survey in Indiana. Purdue Univ. Stat. Bull. No. 645, W. Lafayette, IN.
24. Thompson, D. L., Villena, W. L., and Maxwell, J. D. 1971. Correlations between diplodia stalk and ear rot of corn. Plant Dis. Rep. 55:158-162.

25. Tukey, J. W. 1949. One degree of freedom for nonadditivity. Biometrics 5:232-242.

26. Ullstrup, A. J. 1949. A method for producing artificial epidemics of diplodia ear rot. Phytopathology 39:93-101.

27. Villena, W. L. 1969. Studies of inoculation methods and inheritance of resistance to Diplodia ear rot in corn. Ph.D. diss. North Carolina State University, Raleigh.

28. Warren, H. L. 1982. Registration of H110 and H111 maize germplasm. Crop Sci. 22:12701271.

29. Warren, H. L., and Onken, S. K. 1981. A new technique for evaluating ear rot resistance. (Abstr.) Phytopathology 71:911.

30. Wiser, W. J., Kramer, H. H., and Ullstrup, A. J. 1960. Evaluating inbred lines of corn for resistance to diplodia ear rot. Agron. J. 52:624-626. 